\title{
Modeling of pig growth by S-function - least absolute deviation approach for parameter estimation
}

\author{
Dragutin Vincek1, Kristian Sabo³, Goran Kušec², Gordana Kralik², Ivona Đurkin² and \\ Rudolf Scitovski ${ }^{3}$
}

'Varazdin County, Varazdin, Croatia, ${ }^{2}$ Faculty of Agriculture, Osijek, Croatia, ${ }^{3}$ Department of Mathematics, J. J. Strossmayer University, Osijek, Croatia

\begin{abstract}
The aim of this study was to determine a mathematical model which can be used to describe the growth of the pig. The study was conducted on 60 pigs (30 barrows and 30 gilts) in the interval between the age of 49 and 215 days. All animals were weighed at 49th day after birth. For the purpose of growth measurements pigs were weighted every 7 th day during the experiment. Every 21th day four pigs were selected for the slaughter according to average live weight. By applying the generalised logistic function, the growth of live weight and tissues were described. Thereby optimal parameters in the model were estimated on the basis of measurement data by means of the robust least absolute deviations principle. The prediction of optimum slaughter age/weight, on the basis of such model represent a contribution of this paper to the practice.
\end{abstract}

Keywords: asymmetric S-function, pigs, growth, prediction, body weight, tissue

\section{Introduction}

The pork industry pays for a meat unit exclusively, it is desirable to know until what age/ body weight it is rational to fatten an animal. Traditionally, the changes of body composition during growth are studied using the methods such as dissection of the carcass, computed tomography, magnetic resonance imaging and some other useful techniques at varying age or body weight (Giles et al. 2009). It is a complex problem, especially when it comes to a modelling of the growth patterns. In the depiction of animal growth as the function of time different curves, esspecially from the family of exponential curves, have been used. Indeed, there are many mathematical models succesfully used for analysis and accurate prediction of the animal growth like logistic (Jukić \& Scitovski 2003), von Bertalanfy (Köhn et al. 2007), Gompertz (Vouri et al. 2006), and various forms of generalised logistic functions (López et al. 2000, Scitovski et al. 2006). If some of the dynamic, non-linear functions are selected for modelling, it is important to correctly determine the upper limit of growth, i.e. biological maximum (A) growth of an animal, mature weight or a maximum weight in the point of interest. To obtain the accurate estimations of the final size, it is required that the animals are kept alive beyond a typical market weight which is not a common practice in the case of meat animals. For that reason, in some investigations of pig growth which is based on the maximum growth capacity the final weight is determined experimentally. For example, 
Davies \& Kallweit (1979) established final weight of German Landrace pigs at $200 \mathrm{~kg}$; Walstra (1980) reported final weight of Danish Landrace between 300 and 350 kg; Solanes \& Stern (2001) found this weight to be between 258.4 and $284.8 \mathrm{~kg}$ for Large White. Obviously, this trait is influenced by breed and sex. On the other hand, other authors used predetermined final weight chosen on the empirical knowledge (Kralik et al. 1999, Jelen 1998) or on the combination of empirical knowledge and goodness of fit analysis (Kušec et al. 2007). These authors used asymmetric S-function in their investigations of the pig growth up to $120 \mathrm{~kg}$ live weight setting the biological maximum growth to $220 \mathrm{~kg}$. Similarly the coefficient of asymmetry was empirically set to 0.01. Subsequently, Kušec et al. (2008) showed that asymmetric S-function can be used as a tool in the prediction of live weight, muscle and fat growth of pigs not only within the interval of measurement but throughout the whole time scale. They were able to perform the predictions for individual animal as well as for the group of animals on the basis of the first weighing. In mathematical modelling, one of the frequently occurring problems is to evaluate many parameters simultaneously. Parameters of the growth function are most often estimated on the basis of measurement data by applying the least squares principle (Kušec et al. 2007, Köhn et al. 2007). These nonlinear optimisation problems very often refer to a numerically very demanding and unstable process. Moreover, in practice it is also possible that among the data there might appear severe measurement errors or poor measurement samples known as oultliers. The asymmetric S-function is a good example of the over-determined model where it is difficult to identify all the parameters in every case. For this reason many researchers have chosen to select some parameters on the empirical basis. Having this in mind, the main objective of this paper is to establish a new approach to the modelling of pig growth by asymmetric S-function where the optimal parameters in the model will be estimated on the basis of measurement data by means of the robust least absolute deviations principle.

\section{Material and methods}

The study was carried out on 60 pigs (30 barrows and 30 gilts) during the time interval between 49 and 215 days of age. The pigs were 3 way crossbreds, representing the standard fattening pig type of Batalle breeding programme. First day after farrowing, the piglets were properly marked. Four offspring from one sow (2 barrows and 2 gilts) were selected to enter in the experiment, 15 individuals each. The selected piglets were healthy, with good exterior appearance and appropriately developed body. All animals were weighed at 49th day after birth; subsequently, the pigs were weighted every 7th day during the experiment. Every 21th day 4 pigs were selected for the slaughter according to average live weight. Total dissections of main tissues (muscle, fat and bone) were determined according to Weniger et al. (1963) on the right side of the carcass. During the experiment 3 female animals were excluded due to disease and death. The animals were kept in the same housing and feeding conditions. The pigs were fed ad libitum. The diet provided until $25 \mathrm{~kg}$ average live weight consisted of 13.3 MJ ME/ $\mathrm{kg}$ and $19.6 \%$ crude proteins, and from $25 \mathrm{~kg}$ average live weight until the end of test the diet consisted of $13.6 \mathrm{MJ} \mathrm{ME} / \mathrm{kg}$ and $17.4 \%$ crude proteins. 


\section{Modeling growth}

For the modeling of live weight growth and the growth of the main tissues (muscle, fat and bones), the asymmetric $\mathrm{S}$-function with one flexible inflection point was used. This function is in fact generalised form of logistic function expressed as follows:

$$
f(t)=\frac{A}{\left(1+b e^{-c t t}\right)^{1 / \gamma}}
$$

Parameters $A$ denotes maximum growth capacity in the period of interest, or biological maximum growth; and $g$ is a coefficient of asymmetry which regulates the influence of live weight at certain time $f(t)$ and current biological potential at that time $(A-f(t))$. Model function (1) is also known as generalised logistic function. For this growth function, parameter estimation on the basis of the given measurement data is a very demanding numerical procedure, which cannot always be successfully carried out by ready-made software such as Mathematica (Wolfram Research, Champaign, II, USA), Mathlab (MathWorks, Natick, MA, USA), SAS (SAS Institute Inc., Cary, NC, USA) and Statistica (StatSoft, Inc. Tulsa, OK, USA). In this paper, estimation of the parameter vector $a=(A, b, c, \gamma) \in R^{4}$ for some model growth function $t \rightarrow f(t, a)$ is estimated on the basis of measurement data $\left(t_{i} y_{i}\right), i=1, \ldots, m$, where $0<t_{1}<\ldots<t_{m^{\prime}}$ and $y_{>}>0$, primarily by applying the least absolute deviations principle (Cadzow 2002, Bazaraa et al. 2006). Sometimes, it is possible that among the data severe measurement errors or poor measurement samples known in the literature as »outliers " or »wild points « appear (Watson 1980). Such data might lead not only to unreliable, but very often to wrong conclusions. Assuming that the model-function very well describes the behavior of most data, the least absolute deviations principle can be successfully applied for the purpose of detecting outliers. On the other hand, by using known properties of least absolute deviations approximation it is possible to simplify the minimising function significantly, by which parameters of the growth function are estimated. If the measurement data are contaminated only by normal distributed random errors, least absolute deviations approximation may be used as an excellent initial approximation for searching for the best least squares approximation.

\section{The assessment of the parameters of generalised logistic function using least absolute deviations method.}

If among the measurement data $\left(t, y_{i}\right), i=1, \ldots, m$, some wild points appear, it is reasonable to assess the optimal parameters $\left(A^{*}, b^{*}, C^{*}, \gamma^{*}\right) \in R^{4}$ of the model-function (1) by minimization of the sum of absolute deviations, using LAD (Least Absolute Deviations) method, i.e.

$$
\begin{aligned}
& \min _{(A, b, c, \gamma) \in R^{4}} F(A, b, c, \gamma)=F\left(A^{*}, B^{*}, C^{*}, \gamma^{*}\right) \\
& \text { where } F(A, b, c, \gamma)=\sum_{i=1}^{m} \mid \frac{A}{\left(1+b e^{-c \gamma t i)^{1 / \gamma}}-y_{i} \mid\right.}
\end{aligned}
$$

From the numerical view, minimisation of the non-differentiable functional $F$ with 4 variables is extremely complex and unstable problem which can be reduced to solution of $\mathrm{m}$ problems of minimisation of the 3-variable function (Sabo \& Scitovski 2008). If the assumption is that problem (2) has a solution $A^{*}, b^{*}, c^{*}, Y^{*}$, than: 


$$
F\left(A^{*}, b^{*}, c^{*}, \gamma^{*}\right) \geq \sum_{i=1}^{m}\left|\frac{A\left(b^{*}, c^{*}, \gamma^{*}\right)}{\left(1+b^{*} e^{-c^{*} t_{i}}\right)^{1 / \gamma^{*}}}-y_{i}\right|
$$

where $A\left(b^{*}, c^{*}, \gamma^{*}\right)$ is weighted median of the numbers $y_{i}\left(1+b^{*} e^{-c^{*} \gamma^{*} i}\right)^{1 / y^{*}}, i=1, \ldots, m$ with weights

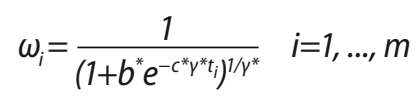

In that sense the equality in (3) holds if $A^{*}=A\left(b^{*}, c^{*}, \gamma^{*}\right)$. According to the properties of the weighted median there exist $\mu \in\{1, \ldots, m\}$ so that $A\left(b^{*}, c^{*}, \gamma^{*}\right)=y_{\mu}\left(1+b^{*} e^{-c^{*} \gamma^{*} t_{\mu}}\right)^{1 / \gamma^{*}}$. If we denote

$$
F_{\mu}(b, c, \gamma)=\sum_{i=1}^{m}\left|\frac{y_{\mu}\left(1+b e^{-c \gamma t_{\mu}}\right)^{1 / \gamma^{*}}}{\left(1+b e^{-c \gamma t i}\right)^{1 / \nu^{*}}}-y_{i}\right|
$$

It is obvious that

$$
\min _{(A, b, c, \gamma) \in R^{4}} F(A, b, c, \gamma)=\min _{\mu=1, \ldots, m, b, c, \gamma,>0} F_{\mu}(b, c, \gamma)
$$

For each $\mu \in\{1, \ldots, m\}$ it is needed to solve the problem of three-dimensional minimisation of the functional $F_{\mu}$ :

$$
\min _{(b, c, \gamma) \in R^{3}} F_{\mu}(b, c, \gamma)=F_{\mu}\left(b_{\mu^{\prime}} c_{\mu^{\prime}} \gamma_{\mu}\right)
$$

For this purpose NMinimize instruction of the program package Mathematica 6.0 (Wolfram Research, Champaign, II, USA) is used. If $\mu^{*} \in\{1, \ldots, m\}$ is such that

$$
\min _{\mu=1, \ldots, m} F_{\mu^{\prime}}\left(b_{\mu^{\prime}} c_{\mu^{\prime}} \gamma_{\mu}\right)=F_{\mu^{*}}\left(b_{\mu^{*}} c_{\mu^{*}}, \gamma_{\mu^{*}}\right)
$$

Than optimal parameters for the solution of the problem (2) are:

$$
b^{*}=b_{\mu^{*}}, c^{*}=c_{\mu^{*}}, \gamma^{*}=\gamma_{\mu^{*}}, A^{*}=y_{\mu^{*}}\left(1-b^{*} e^{-c^{*} \gamma^{*} \mu^{*}}\right)^{1 / \gamma^{*}}
$$

The point of inflection denotes the moment at which progressive growth ceases and growth retardation starts; it is calculated as follows:

$$
I=\left(\frac{1}{c \gamma} \ln \frac{b}{\gamma} ; \frac{A}{(1+\gamma)^{1 / \gamma}}\right)
$$

The stages of growth are determined by the points $t_{B}$ and $t_{C}$ which are calculated according to the following formulae:

$$
t_{B}=\frac{1}{c \gamma} \ln \frac{2 b}{\gamma(\gamma+3)+\gamma \sqrt{(\gamma+1)(\gamma+5)}} \text { and } t_{c}=\frac{1}{c \gamma} \ln \frac{2 b}{\gamma(\gamma+3)-\gamma \sqrt{(\gamma+1)(\gamma+5)}}
$$

Point $B$ denotes a maximum in the region of progressive growth (convex region) and point $C$ is a minimum value in the region of degressive growth (concave region). Interval $\left(t<t_{B}\right)$ is called the stage of preparing growth; $\left(t_{B}<t<t_{C}\right)$ represents the stage of intensive growth and $\left(t>t_{c}\right)$ is the stage of growth retardation. The asymmetric $S$-function was analysed using Mathematica 6.0 program package (Wolfram Research, Champaign, II, USA) and SAS/STAT 9.1 (SAS Institute Inc., Cary, NC, USA) which were also used to prepare some of the figures. 


\section{Results and discussion}

Asymmetric S-function in assessment of maximum live weight growth of pigs

The parameters of asymmetric S-function used in the depiction of live weight growth of investigated pigs are presented in Table 1. Figure 1 shows the resulting growth curve of barrows and gilts included in the study; the curve was fitted to the data using least absolute deviations method. It can be noted that assessed maximum live weight growth was $233.25 \mathrm{~kg}$ for barrows and $179.79 \mathrm{~kg}$ for gilts. Solanes et al. (2005) reported similar pattern of growth in Batalle hybrids, although lower live weight was achieved (average live weight of $102.4 \mathrm{~kg}$ in 179.6 days). In this study to achieve similar average live weight $(103 \mathrm{~kg}$ ) was required less days (163.2 days for barrows and 161.4 days for gilts). Reixach et al. (2008) reported similar results regarding the change of live weight in barrows. At the age of 200 days Duroc pigs had $124.42 \mathrm{~kg}$ and double line Duroc pigs had $121.49 \mathrm{~kg}$. Schinckel et al. (2009) used different nonlinear functions (Bridges, Gompertz and Michaelis-Mentens) for the growth analysis of different pig hybrids. Authors found that Michaelis-Mentens function estimated higher final weight of pigs $(379.3 \mathrm{~kg})$ when compared to Bridges $(238.7 \mathrm{~kg})$ and Gompertz (211.9 kg) function on the same data. Kastelic et al. (1993) estimated final weights (biological maximum) in the interval between $208.51 \mathrm{~kg}$ and $233.67 \mathrm{~kg}$, depending on the model used. The results on growth capacity similar to those shown in the present study were found by Reiland (1978) who predicted maximal live weight of landrace type boars to $235 \mathrm{~kg}$. Koivula et al. (2008) reported that maximal live weights of Finnish Large White (gilts, barrows and boars) were $201.3 \mathrm{~kg}$ on average. The literature values of the final live weights indicate large differences between the breeds (Wellock et al. 2003; Strathe et al. 2010). Beside genetic and environmental influences, estimated weights of pigs can vary because of some models do not estimate final weights correctly.

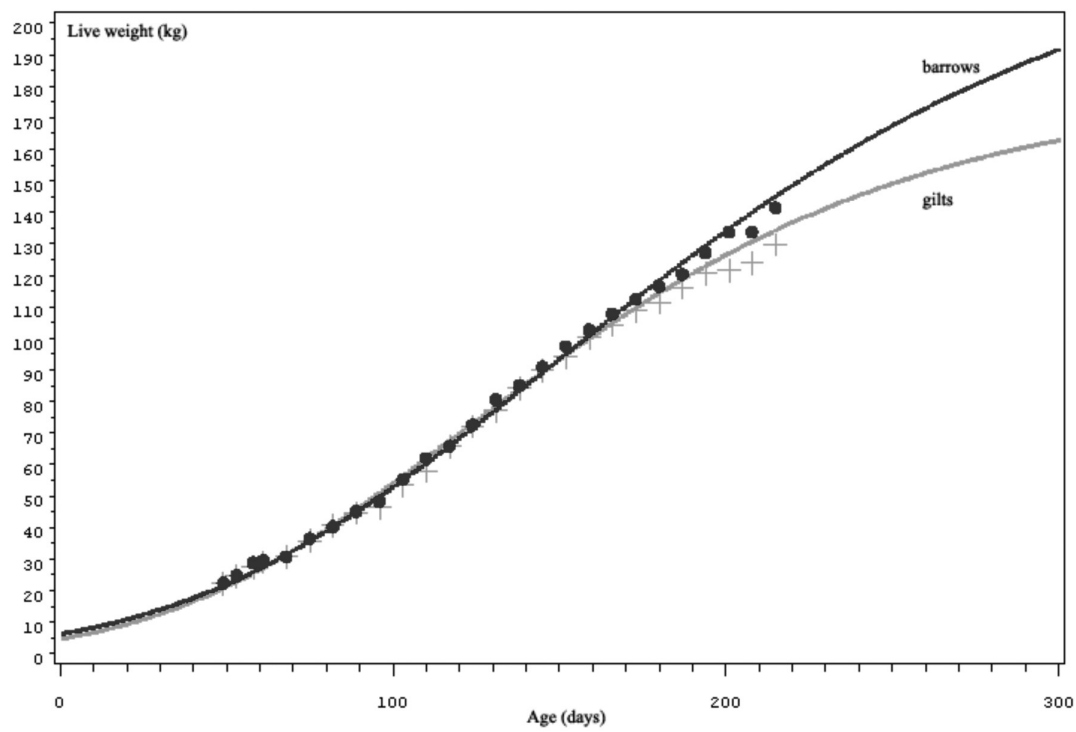

Figure 1

Live weight growth curves of barrows and gilts 
Table 1

Parameters of the asymmetric S-function and the points that determine growth stages of investigated pigs

\begin{tabular}{lcc}
\hline Parameter & Barrows & Gilts \\
\hline $\mathrm{A}^{*}, \mathrm{~kg}$ & 233.25 & 179.79 \\
$\mathrm{Y}^{*}$ & 0.1575 & 0.1463 \\
$\mathrm{~b}^{*}$ & 0.7637 & 0.6975 \\
$\mathrm{C}^{*}$ & 0.0675 & 0.0882 \\
$\mathrm{I}$, days; $\mathrm{kg}$ & $(148.50 ; 92.16)$ & $(121.04 ; 70.70)$ \\
$\mathrm{T}_{\mathrm{B}}$ days; $\mathrm{kg}$ & $(51.64 ; 22.93)$ & $(41.59 ; 17.35)$ \\
$\mathrm{T}_{\mathrm{C}}$,days; $\mathrm{kg}$ & $(245.36 ; 164.80)$ & $(200.48 ; 126.74)$ \\
\hline
\end{tabular}

Asymmetric S-function in depiction of muscle tissue growth

Table 2 shows the parameters of asymmetric S-function used in the depiction of muscle tissue growth of investigated pigs and the points that denote growth stages at the resulting $\mathrm{S}$-curve which is presented in the Figure 2 . From the Figure 2 it can be observed that the growth of barrows and gilts included in this study was described by the model, and that the curve fitted well to the data. The biological maximum of the muscle tissue growth was estimated to $75.79 \mathrm{~kg}$ and $75.74 \mathrm{~kg}$ for barrows and gilts, respectively. Using the model for the growth of live weight, it can be calculated that the point of muscle growth saturation for gilts and barrows is reached at the $102 \mathrm{~kg}$ ( 161.8 days) and $135 \mathrm{~kg}$ (201.2 days) of the live weight, respectively. Since after this point the rate muscle growth is decreasing and weight gain of the pigs is obtained mostly from growth of fat, these points can be regarded as the optimal live weights for slaughter in terms of maximal utilisation of muscle tissue growth. Vincek et al. (2008), using the same principles i.e. combining the information obtained by modeling of live

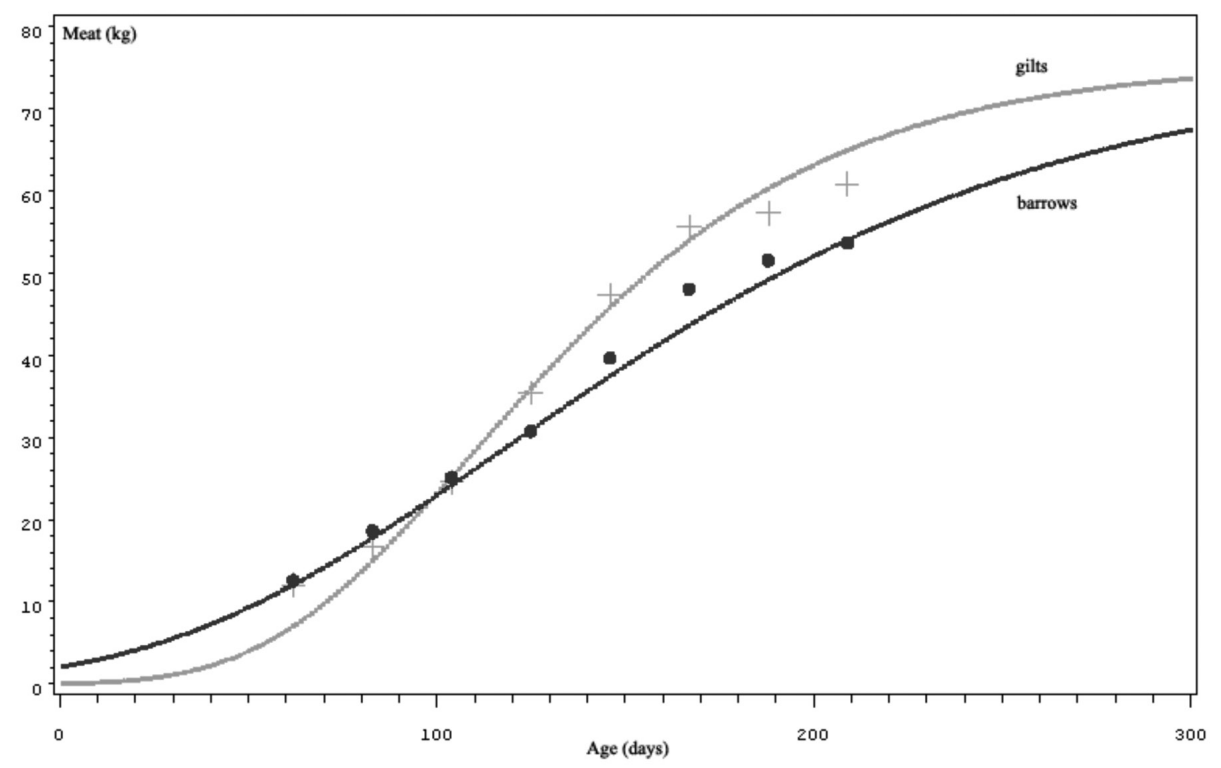

Figure 2

Growth curve of muscle tissue of gilts and barrows 
weight and muscle tissue growth, calculated the optimal slaughter weight to be $130 \mathrm{~kg}$ for intensively fed pigs and $114 \mathrm{~kg}$ for the pigs fed restrictively. Schinckel et al. (2002), predicted muscle mass of $27.2 \mathrm{~kg}, 31.2 \mathrm{~kg}$ and $35.4 \mathrm{~kg}$ at the age of 146,160 and 174 days, respectively. Autors concluded that the rate of muscle mass forming declines at the end of the fattening period, but the time and the rate of the reduced growth depend on the genetic structure of animals.

Table 2

Parameters of growth curve and points which determine stages of muscle tissue growth

\begin{tabular}{lcc}
\hline Parameter & Barrows & Gilts \\
\hline $\mathrm{A}^{*}, \mathrm{~kg}$ & 75.74 & 75.79 \\
$\mathrm{Y}^{*}$ & 0.0676 & 0.0426 \\
$\mathrm{~b}$ & 0.2753 & 0.3443 \\
$\mathrm{C}$ & 0.1756 & 0.4449 \\
$\mathrm{I}$, days; $\mathrm{kg}$ & $(118.28 ; 28.78)$ & $(110.12 ; 28.46)$ \\
$\mathrm{T}_{\mathrm{B}^{\prime}}$ days; $\mathrm{kg}$ & $(34.73 ; 6.36)$ & $(53.39 ; 6.06)$ \\
$\mathrm{T}_{\mathrm{C}^{\prime}}$ days; $\mathrm{kg}$ & $(201.85 ; 52.51)$ & $(161.85 ; 52.25)$ \\
\hline
\end{tabular}

\section{Asymmetric S-function in depiction fat tissue growth}

In Table 3 the parameters of asymmetric S-function and the points which determine the stages of fat tissue growth in the carcasses of studied pigs are shown. The growth of fat tissue of gilts was described using the function with the biological maximum set at $31.1 \mathrm{~kg}$, while the one of barrows was estimated to $62.63 \mathrm{~kg}$. Figure 3 presents the growth of fat tissue of gilts and barrows described using the model with estimated parameters. From the presented results it can be seen that the growth of fat tissue accelerates in the later stages. Similar findings on fat tissue growth were presented by Kouba et al. (1999) in the study of development of various fat depots during the growth of pigs of different carcass composition. When compared to other fat depots, the authors conclude that intramuscular fat develops more in genetically meaty than genetically fatty pigs. According to their opinion, it might be because of selecting reduced subcutaneous fat only.

Later completion of fat tissue growth was determined by many authors (Davies \& Kallweit 1979, Gu et al. 1992), and their results were confirmed in this study as well. Most studies dealing with growth of pigs lead to the conclusion that body weight and back fat thickness significantly differ between breeds and sexes.

Table 3

Growth curve parameters and the points which determine the stages of fat tissue growth

\begin{tabular}{lcc}
\hline Parameter & Barrows & Gilts \\
\hline $\mathrm{A}^{*}, \mathrm{~kg}$ & 62.64 & 31.10 \\
$\mathrm{Y}^{*}$ & 0.0457 & 0.0475 \\
$\mathrm{~b}^{*}$ & 0.25916 & 0.2322 \\
$\mathrm{C}^{*}$ & 0.1799 & 0.2331 \\
$\mathrm{I}$, days; $\mathrm{kg}$ & $(210.98 ; 23.56)$ & $(143.00 ; 11.71)$ \\
$\mathrm{T}_{\mathrm{B}^{\prime}}$ days; $\mathrm{kg}$ & $(91.51 ; 5.04)$ & $(54.35 ; 2.51)$ \\
$\mathrm{T}_{\mathrm{C}^{\prime}}$ days; $\mathrm{kg}$ & $(330.45 ; 43.21)$ & $(231.66 ; 21.46)$ \\
\hline
\end{tabular}




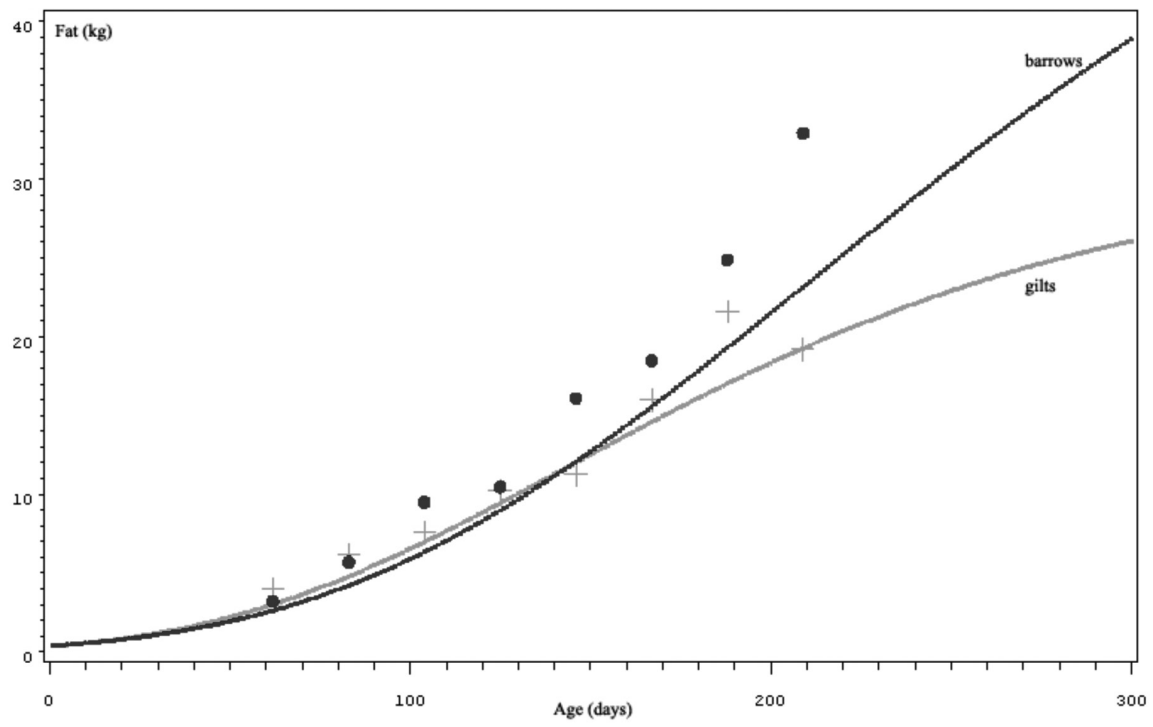

Figure 3

The curve of fat tissue growth of barrows and gilts

\section{Asymmetric S-function in depiction bone growth}

In this study bone growth increases proportionally with the body, and estimated parameters of the curve are shown in Table 4 and Figure 4. Bone growth of gilts is described using the function with the biological maximum set at $10.94 \mathrm{~kg}$, while the one of barrows was estimated at $32.75 \mathrm{~kg}$. The stage of intensive bone growth of the studied barrows lasted approximately 419 days. Furugouri et al. (1981) reported that the increase of body weight is proportional to the increase of length and diameter of bones in pigs between 30 and $150 \mathrm{~kg}$, which shows that the shape of bones is formed in the earliest stage of growth. Exploring the influence of a breed on the proportion of bones in pig carcasses, Žgur et al. (1995) reported that larger percentage of bones was found in Duroc crossbreeds when compared to other genotypes. Bone development is faster in younger animals, but starts to decline when an animal reaches a market weight. Although the rate of bone growth slowly declines as the animal enters later stages of life, the skeleton is still growing, only considerably more slowly.

Table 4

Parameters of growth curve and the points which determine stages of bone growth

\begin{tabular}{lcc}
\hline Parameter & Barrows & Gilts \\
\hline $\mathrm{A}^{*}, \mathrm{~kg}$ & 32.75 & 10.94 \\
$\mathrm{Y}^{*}$ & 0.0507 & 0.2107 \\
$\mathrm{~b}^{*}$ & 0.1737 & 0.9137 \\
$\mathrm{C}^{*}$ & 0.0927 & 0.0706 \\
$\mathrm{I}$, days; $\mathrm{kg}$ & $(262.09 ; 12.35)$ & $(98.64 ; 4.42)$ \\
$\mathrm{T}_{\mathrm{B}^{\prime}}$ days; $\mathrm{kg}$ & $(52.62 ; 2.66)$ & $(27.96 ; 1.17)$ \\
$\mathrm{T}_{\mathrm{C}^{\prime}}$ days; $\mathrm{kg}$ & $(471.56 ; 22.62)$ & $(169.31 ; 7.81)$ \\
\hline
\end{tabular}




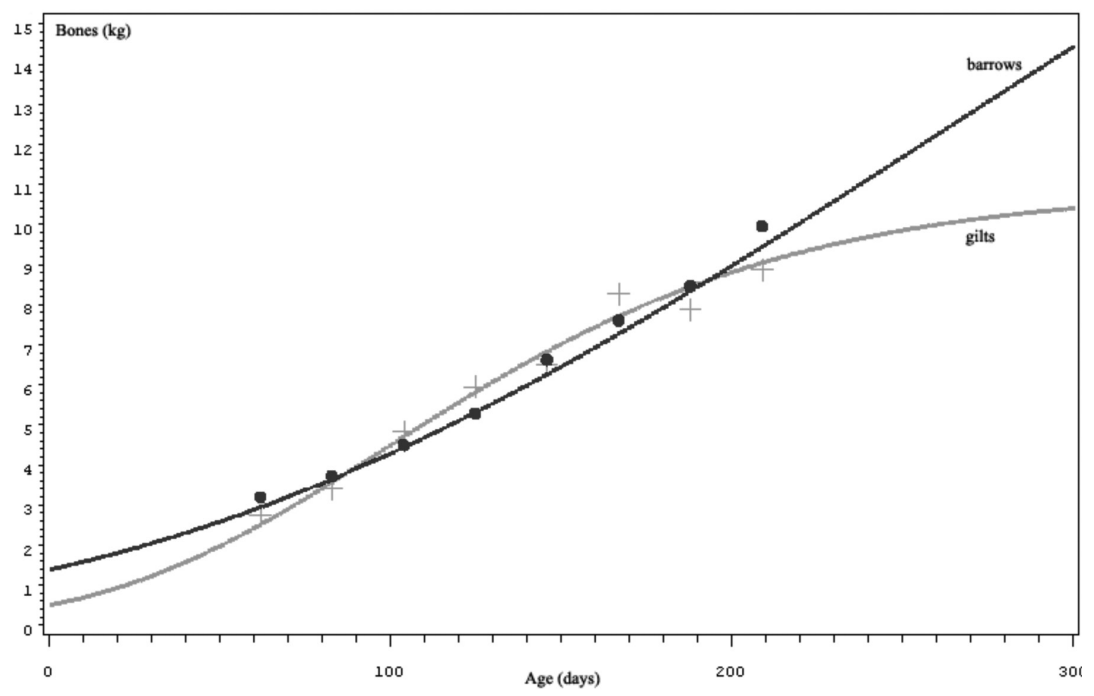

Figure 4

Growth curve of bones of barrows and gilts

In present study, the biological maximum of growth and coefficient of asymmetry, in contrast to previous studies, was calculated on the basis of recorded data on the growth of live weight. Data obtained by dissection of sacrificed animals were used to calculate the biological maximum (A) of the tissues and their coefficient of asymmetry. Asymmetric S-curve appears to be a good mathematical model for the prediction of live weight and muscle tissue growth, while fat tissue and bone growth were not described so well. Consequently, there is a need of constant review of the tools in the assessment of growth of certain tissues in commercial pig production. Estimation of the maximum growth of live weight and the weight of economically important tissues of pigs based on the collected data proved to be possible, despite the large number of parameters included in the model. The prediction of optimum slaughter age/weight, on the basis of such model represent a contribution of this paper to the practice.

\section{References}

Bazaraa MS, Sherali HD, Shetty CM (2006) Nonlinear Programming. Theory and Algorithms. 3rd ed., John Wiley \& Sons, New Jersey, CA, USA

Cadzow JA (2002) Minimum $I_{1}, I_{2}$ and $I_{\infty}$ Norm Approximate Solutions to an Overdetermined System of Linear Equations, Digit Signal Process 12, 524-560

Davies AS, Kallweit E (1979) The effect of body weight and maturity on the carcass composition of the pig. Z Tierzuechtg Zuechtgsbiol 96, 6-17

Furugouri K, Kawabata A, Kusuhara S (1981) Growth of limb bones in pigs. Jpn J Zootech Sci 52, 297-307

Giles LR, Eamens GJ, Arthur PF, Barchia IM, James KJ, Taylor RD (2009) Differential growth and development of pigs as assessed by X-ray computed tomography. J Anim Sci 87, 1648-1658

Gu Y, Schinckel AP, Martin TG (1992) Growth, development, and carcass composition in five genotypes of swine. J Anim Sci 70, 1719-1729 
Jelen T (1998) [Research on growth of pigs of different genotypes]. Master Thesis, Faculty of Agriculture, University J.J. Strossmayer, Osijek, Croatia [in Croatian]

Jukić D, Scitovski R (2003) Solution of the least-squares problem for logistic function. J Comp Appl Math 156, 159-177

Kastelic M, Kovač M, Šalehar A (1993) [Contribution to the study of differential growth on non-linear statistical models]. Zbornik Biotehniške fakultete Kmetijstvo, Zootehnika 62, $85-97$ [in Slovenian]

Köhn F, Sharifi AR, Simianer H (2007) Modeling the growth of the Goettingen minipig. J Anim Sci 85, 84-92

Koivula M, Sevón-Aimonen ML, Strandén I, Matilainen K, Serenius T, Stalder KJ, Mäntysaari EA (2008) Genetic (co)variances and breeding value estimation of Gompertz growth curve parameters in Finnish Yorkshire boars, gilts and barrows. J Anim Breed Genet 125, 168-175

Kouba M, Bonneau M, Noblet J (1999) Relative development of subcutaneous, intermuscular, and kidney fat in growing pigs with different body compositions. J Anim Sci 77, 622-629

Kralik G, Jelen T, Scitovski R, Kušec G (1999) Analysis of phenotypic expression and growth of gilts using asymmetric $S$-function. Krmiva 41, 159-165

Kušec G, Baulain U, Kallweit E, Glodek P (2007) Influence of MHS genotype and feeding regime on allometric and temporal growth of pigs assessed by magnetic resonance imaging. Livest Sci 110, 89-100

Kušec G, Kralik G, Đurkin I, Baulain U, Kallweit E (2008) Optimal slaughter weight of pigs assessed by means of the asymmetric S-curve. Czech J Anim Sci 53, 98-105

López S, France J, Gerrits WJJ, Dhanoa MS, Humphries DJ, Dijkstra J (2000) A generalised Michaelis-Menten equation for the analysis of growth. J Anim Sci 78, 1816-1828Reiland S (1978) The effect of decreased growth rate on frequency and severity of osteochondrosis in pigs. Acta Radiol Suppl 358, 107-122

Reixach J, Tor M, Diaz M, Estany J (2008) Between and within breed variation for lean growth and intramuscular fat content and fatty acid composition in pigs. 54th International Congress of Meat Science and Technology, ICoMST, Helsinki, Finland, 1-3

Sabo K, Scitovski R (2008) The best least absolute deviations line-properties and two efficient methods its derivation. ANZIAM 50, 185-198

Schinckel AP, Li N, Einstein ME, Miller D (2002) Development of a Stochastic Pig Compositional Growth Model, http://www.ansc.purdue.edu/swine/swineday/sday02/15.pdf [last accessed 23.07.2012]

Schinckel AP, Einstein ME, Jungst S, Booher C, Newman S (2009) Evaluation of Different Mixed Model Nonlinear Functions to Describe the Body Weight Growth of Pigs of Different Sire and dam Line. Prof Anim Sci 25, 307-324

Scitovski R, Kralik G, Sabo K, Jelen T (2006) A mathematical model of controlling the growth of tissue in pigs. Appl Math Comput 181, 1126-1138

Solanes FX, Stern S (2001) Estimated Mature Weights and Growth Curves for Large White Sows. Acta Agric Scand, Sect A, Anim Sci 51, 142-147

Solanes FX, Reixach J, Tor M, Tibau J, Estany J (2005) Genetic correlation of intramuscular fat content with performance traits and litter size in Duroc pigs. 56th Annual Meeting of European Association for Animal Production (EAAP). June 5-8, Uppsala, Sweden, 11, 307-308

Strathe AB, Danfaer A, Sørensen H, Kebreab E (2010) A multilevel nonlinear mixed-effects approach to model growth in pigs. J Anim Sci 88, 638-649

Vincek D, Đurkin I, Kralik G, Petričević A, Baulain U, Kušec G (2008) [Influence of feeding regime on pig growth characteristics]. Krmiva 50, 63-72 [in Croatian]

Vuori K, Stranden I, Sevon-Aimonen ML, Mantysaari EA (2006) Estimation of non-linear growth models by linearization: a simulation study using a Gompertz function. Genet Sel Evol 38, 343-358

Walstra P (1980) Growth and carcass composition from birth to maturity in relation to feeding level and sex in Dutch Landrace pigs. PhD Thesis, University of Wageningen, The Netherlands

Watson GA (1980) Approximation theory and numerical methods. John Wiley \& Sons, Chichester, UK 
Wellock IJ, Emmans GC, Kyriazakis I (2003) Modelling the effects of thermal environment and dietary composition on pig performance: model logic and concepts. Anim Sci 77, 255-266

Weniger HJ, Steinhauf D, Pahl G (1963) Musculature topography of carcasses. BLV Verlagsgesellschaft, Munich, Germany

Žgur S, Kovač M, Šegula B (1995) [Influence of genotype on tissue growth in pigs from 60 to $150 \mathrm{~kg}$ live weight]. Zbornik Biotehniške fakultete, Kmetijstvo (Zootehnika), Suppl 22, 131-137 [in Slovenian]

Received 31 August 2011, accepted 21 March 2012.

Corresponding author:

Dragutin Vincek

email: dragutin.vincek@varazdinska-zupanija.hr

Varazdin County, Department of Agriculture, Franjevacki Trg 7, 42000 Varazdin, Croatia 